\title{
AN AMICABLE AGREEMENT OR ANOTHER FORM OF DEBT RESTRUCTURING IN INSOLVENCY PROCEDURE FOR INDIVIDUALS IN LATVIA
}

\author{
Renata Konopecka ${ }^{1}$
}

\begin{abstract}
The goal of this article is to explore the features of using insolvency proceedings in Latvia and to elaborate on special proposals for modernizing the laws. In the legislation, there has been no prospect from a legal perspective to restructure an individual's debts. Namely, individuals have no opportunity to use legal protection within the framework of the insolvency proceedings to reach an amicable agreement with creditors, or create another form of debt restructuring. Eliminating this gap in legislation is therefore necessary.
\end{abstract}

In this article, analytical, comparative, historical and deductive methods are used to explore the legal norms that regulate the insolvency proceedings for an individual. The aim is to identify the distinctive features of the proceedings; to analyze the problematic aspects of laws and develop proposals for modernizing the legislation of Latvia in this field. The novelty of this research pertains to it being the first attempt in Latvia to examine the question of legal regulation of insolvency proceedings in complexity, with a practical proposal to improve Latvian legal norms and avoid bankruptcy problems. The outcome of this study includes a proposal to supplement the Act on Insolvency with the Article "Amicable Agreement", for deciding upon the state of insolvency. This relates to an agreement between the creditors and the debtor to fulfil obligations before an auction of the debtor's property.

UDC Classification: 347.9 DOI: http://dx.doi.org/10.12955/cbup.v4.805

Keywords: agreement, arrangement, bankruptcy, individual, insolvency, proceeding, legal, voluntary.

\section{Introduction}

The law that regulates the process of insolvency of an individual is the subject to continuous changes. Nevertheless, law enforcement practices witness insufficient and clear legal regulation and there is a need for modernizing legislation. This study involves a comparative legal analysis of three legislative acts of the Republic of Latvia: Laws On the Insolvency of Undertakings and Companies (1996 Act on Insolvency (2007), which first regulated the insolvency process of individuals and the current Act on Insolvency (2010). It also involves analyzing the views of different scholars on the necessity and possibility of the use of the amicable agreement to resolve the civil dispute, as well identify an exit in the state of a debtor's insolvency.

Bartoshek in Roman Law (1989) described an opportunity to resolve a property dispute amicably with the help of an extrajudicial informal agreement that was well-known in Ancient Rome.

An honorary senator of the Supreme Court of the Republic of Latvia Aigars (2011) considered an amicable agreement as a very successful outcome of any civil case, where it followed the conditions without deception, coercion errors. An honorary senator, academician of the Latvian Academy of Sciences Professor Torgans investigated the legal nature of the amicable agreement.

Associate professor of Moscow State University Karelina (2007) in 'Legal regulation of insolvency', examined the essence of the amicable agreement the debtor and the creditors at any stage of the bankruptcy case in the arbitration court.

To investigate the legal possibility of debt restructuring and to develop proposals to improve legislation, this study examined the following acts of other European countries: Act on the Adjustment (1993) of Finland, Bankruptcy Law and its resolution (Insolvency Act) of Czech Republic, Debt Restructuring and Debt Protection Act (2010) of Estonia, and certain legislative acts of the Russian Federation regarding the regulation of rehabilitation procedures applicable to a citizen-debtor: Federal Law No. 127-FZ On Insolvency (Bankruptcy; 2002) of the Russian Federation and Federal Law No. 154-FZ On settlement features of insolvency (Bankruptcy; 2015).

Therefore, this article discusses the ways to resolve the legal regulation of the state of insolvency. analyses how changes in the legislation affected the possibility for certain debtors to use an amicable agreement as a way to resolve their state of insolvency to identify the gaps and contradictory aspects in

\footnotetext{
${ }^{1}$ Renata Konopecka, Baltic International Academy, Riga, Latvia, juridiskafirma @yandex.com
} 
this field. As a result, it elaborates proposals to improve the legislation of Latvia governing the insolvency process of an individual.

This article aims to identify the necessity to improve the legislation of Latvia in the field of the insolvency process of an individual with changes to allow individuals to restructure their debts without bankruptcy.

The novelty of the article pertains to the complex issue of legal regulation of the state of insolvency and a proposal to improve the legislation on insolvency of an individual in Latvia, which has not been considered until now.

The research results have allowed formulation of a suggested amendment to the enactment of the Act on Insolvency (2010).

\section{Materials and Methodology}

To achieve the goals and objectives analytical, comparative, historical and deductive methods are used. The analytical and comparative methods are two of the main research methods used in the study of legal scientific literature, court decisions, legislative, and other legal sources. They are also used to identify common features, including differences and weaknesses, in the regulation of the insolvency proceeding of an individual in the legislation of Latvia and other countries. The deductive method was applied to analyse similarities and patterns of legal regulation of insolvency of individuals to develop specific proposals to amend the law for the use of these changes in practice. The historical method was applied to study the order of the regulation for an amicable agreement in its historical development.

\section{A Comparative Legal Analysis of Three Legislative Acts of the Republic of Latvia}

In the Law of Latvian Republic 'On the Insolvency of Undertakings and Companies', which came into force in 1996, three possible ways exist to resolve the state of insolvency as envisaged for the debtors (legal entities). The first was the amicable agreement, the second the readjustment (financial rehabilitation), and the third, bankruptcy. According to the Law On the Insolvency of Undertakings (1996), the debtor is an undertaking or a company that is unable to fulfil its contractual obligations and, therefore, the law did not provide for the bankruptcy of an individual.

The Act on Insolvency (2007) was the first legislation to regulate insolvency, not for legal entities only, but also for individuals. According to the Law of Latvian Republic Act on Insolvency (2007), insolvency of an individual requires a set of legal measures that aim to satisfy the creditors' claims of the debtor's property, as much as possible, and allow the debtor, whose property and income are insufficient to repay all obligations, to be released from the unfulfilled commitments and restore his or her solvency. In the articles of the Act on Insolvency (2007, the methods used to reach an amicable agreement, the requirements of its draft, and the procedure of its approval, as well as the consequences of reaching an amicable agreement, were legalized (Act on Insolvency, 2007, Articles 170 - 174).

Thus, Latvian Laws, On the Insolvency of Undertakings (1996), and the Act on Insolvency (2007), provided ways for an amicable agreement or bankruptcy with the task to resolve the state of insolvency, expressed as a set of financial, legal, and organizational measures, and the aim to satisfy the creditors' claims in a more complete way (including the possibility of an amicable settlement).With this, the Act on Insolvency (2007) had legislated a method of resolving insolvency as an amicable agreement for legal entities and individuals.

Since November 1, 2010, the insolvency proceedings of individuals and legal entities in Latvia have been regulated by the Act of Insolvency (2010). According to this, legal entities (companies) in a state of insolvency are provided legal protection, including out-of-court legal protection. This possibility to reach an amicable agreement and claim readjustment were unavailable for all categories of debtors. The Act of Insolvency (2010) only provided one-way solution for individuals, the procedure of bankruptcy. Hence, there was disproportion between debtors.

According to the Action Plan of Improvement of Cabinet of Minister's (2009), Latvian's current legislation failed to ensure the effectiveness of the insolvency proceedings and this led to the increased processing time and costs. For example, in accordance with the Act on Insolvency (2007), a creditors' meeting was required to consider the possibility of using procedures for readjustment or an amicable agreement, and only then could they consider the declaration of a bankruptcy procedure. 
Letter of Intent (2009) explained the need to streamline liquidation procedures to facilitate rapid exit of non-viable firms, and further improve the foreclosure process by addressing remaining inefficiencies that hinder debt resolution.

In accordance with the action plan for the Latvian Cabinet of Ministers' Implementation (2009), Action Plan of Improvement (2009) changes were initiated and then adopted to abolish the two traditional ways of resolving the state of insolvency: readjustment and amicable agreement reducing the risk for creditors.

It should be noted that the Act on Insolvency (2010) provided convenience (reduced time of the process) and a significant reduction in the price of an individual's insolvency, as well as an opportunity to save the pledged property through an arrangement with the creditors. A debtor in Latvia must pay a one-time fee to the administrator in the amount of two minimum salaries, which is twentynine times less than was envisaged in the previous Act on Insolvency (2007). Hence, the individual's plan of debt repayment can take from one to three and a half years, instead of the previous five seven.

To help a legal entity, such as a debtor, dispose of debts and financial difficulties, the Act of Insolvency (2010) provided an opportunity to restructure debt through the procedure for legal protection of legal entities. At the start of the procedure for legal protection, the debtor is guaranteed to have judicial protection from individual creditors, a reduction in the number of claims, and a decrease in interest; it was also possible to reorganize companies. A debtor who had initiated negotiations with creditors before the trial, but was unable to reach an agreement with all creditors, had the opportunity to ask the court to develop a plan of legal protection using a majority of unsecured creditors. Thus, with the support of creditors, a legal entity could restore solvency. However, for the individual debtor the option of legal protection was unavailable.

During the preparation of the Act of Insolvency (2010), the legal insolvency of individuals was not considered, and, therefore, the need to provide an opportunity to restructure their debts through the introduction of legal protection or a possibility for an amicable agreement, was not identified, as in the Act on Insolvency (2007).

\section{Individual Voluntary Arrangements}

Milan Bartoshek in Roman Law (1989) pointed to the well-known Ancient Rome form of resolution for property dispute transaction (from the Latin transigere, to dispute, to negotiate), as an amicable settlement and an out-of-court informal agreement where the parties cease dispute or remove legal uncertainty by mutual concession. The amicable settlement (transactio) could serve as the legal basis for various property problems.

In modern law, an amicable agreement is a civil transaction, which commences immediately after the court approves the terms and conditions agreed by the parties. In creating this agreement, the parties cease to dispute and remove uncertainties in their legal relationship through mutual concession without needing to cancel, or annul it.

The concept of amicable agreement is enshrined in the Law of Latvian Republic Civil Law (1937, Article 1881): "amicable settlement is an agreement according to which the legal relations from disputable or otherwise causing some doubts turn into indisputable and undeniable through mutual concessions of its participants".

The academician of the Latvian Academy of Sciences Professor Kalvis Torgans considered each part of the agreement fully or partially and refused its claim, instead defining a new one from the requirement for an amicable agreement (Dubure et al., 1998, p.91).

Honorary Senator of the Supreme Court Gunars Aigars et al. (2011) considered an amicable agreement to be a highly successful completion of any civil case, where its conditions indicate it has been conducted without fraud, coercion, threat, or misleading, free will. Aigars (2011) considered the parties to know better factual circumstances of legal relations than that imposed by the Civil Procedure Law (Part 3 of Article 151) in the duty of the court to reconcile the parties.

An amicable agreement, as the resolution of the state of insolvency had its own characteristics for insolvency (for bankruptcy law). 
Consolidating legislation in various ways to resolve the state of insolvency has been a traditional approach. For instance, Bankruptcy Law and its resolution (Insolvency Act, 2006) of the Czech Republic provided the following ways in the event of a threat from debtor insolvency: bankruptcy, reorganization, debt relief and special ways to deal with bankruptcy. In case of reorganization, the court was provided with a permit of reorganization, and in case of debt cancellation, with a decision on debt relief.

The associate professor of Moscow State University Karelina (2007) believed that an amicable agreement is a voluntary one between a debtor and creditors on settling a property dispute on certain conditions at any stage of a bankruptcy case in the arbitration court.

In the law, On the Insolvency of Undertakings (1996, point 13 of Article 1), an amicable agreement is a decision on the state of insolvency, which is expressed as an agreement between creditors and a debtor on meeting the debtor's requirements in the case and manner prescribed by law. In this case, an amicable agreement was permitted at all stages of insolvency before the auction of the debtor's property.

Article 77 of the On the Insolvency of Undertakings (1996) provided for the need to consider the possibility of an amicable agreement at the first meeting of creditors where signing was offered by the debtor or creditors. At the next meetings of creditors, the issue of the amicable agreement is to be considered only where it included into the agenda for the creditors' meeting. The administrator was required to include the issue of the amicable agreement into the agenda for the creditors' meeting. The draft of the amicable agreement, proposed by the debtor or creditors, was required to be transferred to the administrator, no later than three weeks before the scheduled date of the creditors' meeting.

In some countries, there are special regulations governing the restructuring of an individual's debt. In Finland there exists the Act on the Adjustment (1993), which allows for improving the insolvent debtor's financial position by a court decision concerning the debtor's obligations for approving a program of payment that corresponded to his or her abilities.

Thus, in accordance with the evaluation of the International Bank for Reconstruction and Development (The World Bank) in the Economy Profile (2016, p. 15), Finland ranked first out of 189 countries in the overall ranking of the effectiveness of the insolvency proceedings. Insolvency proceedings in Finland lasts an average of 0.9 years, and the costs of the proceedings comprise 3.5 percent of the value of the debtor's property; and on average, 90.2 cents of every US dollar are returned in Finland.

In Estonia, the Debt Restructuring and Debt Protection Act (2010) is used for restructuring individuals' debts. Estonia has a fairly high rate of efficiency of insolvency proceedings 14 of 16, which indicates the high quality of the process and its compliance with international standards.

In the UK, Keay and Walton (2003, p. 155) proposed "in the same way that companies may enter into company voluntary arrangements with their creditors, so too individuals may enter individual voluntary arrangements with their creditors and considered:

the individual voluntary arrangements is a way to avoid bankruptcy (an IVA can even be approved after the debtor has been made bankrupt). It is more effective than a purely informal arrangement as, once it is approved, it will bind all the debtor's creditors. No one creditor of the debtor can break ranks and petition for the debtor's bankruptcy. (p. 155)

The decision to reach an amicable agreement is usually accepted at the creditors' meeting by a majority vote from the total number of creditors, in accordance with registry requirements, and is considered adopted where the majority of creditors have voted for it. This differs among countries, for example, in the UK, the decision transpires with a 75 percent affirmative vote from creditors on all liabilities and in Russian Federation, this requires a 100 per cent affirmative vote under the obligations secured by a pledge of the debtor's property.

Such legal regulation allows the debtor an opportunity to promptly deal with financial problems. It appears necessary to eliminate the gap in the law, which no longer allows an individual to legally resolve the issue of his or her solvency restoration through an agreement to settle a property dispute with the creditors. 
An amicable agreement with creditors should be possible both before the application of insolvency to the court and after the declaration of insolvency, and at any stage of the process prior to the auction of the debtor's property. However, in reaching an amicable agreement, the parties lose their previous rights and duties, in certain capacities, with commencement of the special terms of this agreement. This study proposes supplement to the Act on Insolvency (2010) with the Article 137.1. It proposes the Amicable Agreement with the following text:

Amicable agreement is a decision on the state of insolvency, which is expressed as an agreement between the creditors and the debtor regarding the fulfilment of obligations before the auction on the debtor's property of the debtor and should be made in written form. The agreement is signed by the debtor and one representative from the creditors elected at the creditors' meeting. The terms included into the draft of an amicable agreement are determined by the creditors' meeting. The terms of the amicable agreement should note the number of claims of each group of creditors. The following items may be used in the amicable agreement: 1) reduction in the number of claims; 2) waiver of penalty or interest, including default interest, either from the penalty and interest, or their reduction; 3) postponement of the execution of obligations. The powers of the creditor's representative to vote on the question of making the amicable agreement should be specifically provided in the letter of attorney. The amicable agreement is considered to be made if it has been voted for by: 1) more than two-thirds of the creditors, summarizing the main debt of each one, if the project foresees the satisfaction of the requirements of less than half of the amount of the main debt; 2) more than half of the creditors, summarizing the principal amount of each one, if the project foresees the satisfaction of the requirements of more than half of the total amount of the main debt. If the amicable agreement is not made, the creditors' meeting should decide on the initiation of bankruptcy proceedings or other actions on the state of insolvency. The amicable agreement should commence after its approval by the court. The court has no right to change the content of the amicable agreement. The terms of the amicable agreement are obligatory to be observed by all creditors. After the approval of the amicable agreement by the court, the procedure in the case of insolvency finishes, and the termination of the amicable agreement between separate creditors and the debtor is not allowed. The creditor as well as the group of creditors may apply to the court for the cancellation of the amicable agreement, if the debtor fails to comply with the terms and conditions of the obligations stipulated by the amicable agreement. The question of the abolition of the amicable agreement is decided by the court. Simultaneously, the court may decide on the initiation of bankruptcy proceedings. In case of the cancellation of the amicable agreement the creditors whose claims have been settled by the amicable agreement, have the right to declare their claims to the debtor in the composition and in the amount stipulated by this agreement.

\section{Conclusion}

This study of the legal regulations of other European countries and the analysis of law enforcement practice has revealed that in the Act on Insolvency (2010) there is no resolution for the legal aspect of restructuring of an individual's debts. Namely, individuals have no opportunity to use legal protection, within the framework of the insolvency proceedings, to reach an amicable agreement with creditors or to create another form of debt restructuring.

Thus, in Latvia, the legislation governing an individual's insolvency has gaps that deem the procedure inefficient and unavailable for certain individuals. To achieve efficiency in the process that is regulated by the Act on Insolvency (2010), it is necessary to eliminate gaps in the legislation.

The objectives of this article were to explore the features of insolvency proceedings towards certain categories of debtors, and to elaborate special proposals for modernizing the legal regulation of these proceedings in terms of an individual in Latvia. This study has proposed an Amicable Agreement as a supplement to the Act on Insolvency (2010) with Article 137.1

\section{References}

Aigars, G., Rozenbergs, J. \&Torgans, K. (2011). Comments of Civil Procedure Law. Part I (from Chapter 1 to 28). Riga: Tiesu nama agentura.

Action Plan for Improvement of Business Environment (2009). Order of the Cabinet of Ministers of the Latvian Republic No. 35. Order of the Cabinet of Ministers of the Latvian Republic No. 365. 
Act on the Adjustment of the Debts of a Private Individual of the Republic of Finland.(1993). Retrieved from http://www.finlex.fi/fi/laki/ajantasa/1993/19930057

Act on Insolvency of the Latvian Republic (2007). Text in English from

http://www.vvc.gov.lv/advantagecms/LV/tulkojumi/meklet_dokumentus.html?query=Maks\%C4\%81tnesp\%C4\%93jas+liku ms\&searchPage $=3 \&$ resultsPerPage $=10$

Act of Insolvency of the Latvian Republic (2010). Retrieved from http://likumi.lv/doc.php?id=214590

Bartoshek, M. (1989). Roman law. Concepts, terms, definitions Moscow.

Bankruptcy Law and its resolution (Insolvency Act) of the Czech Republic (2006). Retrieved from http://www.zakonyprolidi.cz/cs/2006-182

Civil Law of the Latvian Republic. Fourth Part. Liability Law. (1937). Retrieved from http://likumi.lv/doc.php?id=90220

Debt Restructuring and Debt Protection Act of the Republic of Estonia. (2010). Retrieved from https://www.riigiteataja.ee/akt/V\%C3\%95VSs

Dubure, V., Fogels, A., Fridrihsons, I., Indulens, G., Krastinsh, I. \& Krastinsh, U. (1998). Glossary of Legal Terms. Riga: Nordic.

Economy Profile 2016. Finland.(2016). Doing Business, 15. Retrieved from http www.doingbusiness.org/data/ exploreeconomies/ /media/giawb/doing\%20business/documents/profiles/country/FIN.pdf?ver=2

Federal Law of the Russian Federation No. 127-FZ On Insolvency (Bankruptcy) (2002). Retrieved from http://finlawyer.ru/2015/127-fz-of-october-26-2002-on-insolvency-bankruptcy/

Federal Law of the Russian Federation No. 154-FZ On settlement features of insolvency (bankruptcy) in the territory of the Republic of Crimea and the federal city of Sevastopol and On Amending Certain Legislative Acts of the Russian Federation (2015). Retrieved from

$\mathrm{http} / /$ www.consultant.ru/cons/cgi/online.cgi?req=doc\&base $=\mathrm{LAW} \& \mathrm{n}=200071 \& \mathrm{fld}=134 \& \mathrm{dst}=1000000001,0 \& \mathrm{rnd}=0.77545$ 27056509486

Implementation action plan of stabilization and growth program for Latvian economic (2009). Order of the Cabinet of Ministers of the Latvian Republic No. 123.

Karelina, S. (2007). Legal regulation of insolvency (bankruptcy).Moscow: Wolters Kluwer.

Keay, A. \& Walton, P. (2003). Insolvency Law: Corporate and Personal. Harlow Pearson education Limited. p. 155.

Letter of Intent of the government of Republic of Latvia, addressed to the International Monetary Fund (2009). Retrieved from http://www.imf.org/External/NP/LOI/2009/lva/072709.pdf

On the Insolvency of Undertakings and Companies. Law of the Latvian Republic (1996). text in English retrieved from http://www.vvc.gov.lv/advantagecms/LV/tulkojumi/meklet_dokumentus.html?query=Par+uz\%C5\%86\%C4\%93mumu+un+uz \%C5\%86\%C4\%93m\%C4\%93jsabiedr\%C4\%ABbu+maks\%C4\%81tnesp\%C4\%93ju\&Submit=Mek1\%C4\%93t\&resultsPerPag $\mathrm{e}=10$ 